\title{
Predicting recovery from muscle strains, a new take on "inflammation" and the Goldman Dilemma
}

\author{
Andrew P Garnham
}

Muscle strains are common. In clinical practice, we find several scenarios. Recreational athletes have concerns as to what the injury is and how long will it take to recover. Another group of patients are those who have recurrent muscle strains. Patients know what they have done (yet again), but now want to know how to prevent recurrence. A third group are competitive athletes across all sports - they want everything! Their concern centres on how quickly they can recover and how to minimise the chance of re-injury at the same time! This is especially important when finals and championships are upcoming, and at the professional level. Strategies for dealing with muscle strains are in the main time honoured rather than strongly evidence based, and it has been oft stated that there are many avenues of potential research.

In this issue, Balius and colleagues ${ }^{2}$ (see page 818) offer a sound basis for measuring the extent of injury to the rectus femoris in soccer players. This information, which should be valid across all running sports, relies on ultrasound as a relatively cheap and safe tool. Once diagnosis and prognosis have been confirmed, what to do next? Tradition has been to make use of non-steroidal antiinflammatory drugs (NSAID), but increasingly their role is being questioned. Will they accelerate healing time? Or will healing time be similar, or slightly longer, but return to function occurs a little sooner? Is there an increased risk of recurrence with early return when NSAID are used? Will bleeding be greater in the presence of NSAID should a further injury occur? In this issue, Paoloni and colleagues $^{3}$ (see page 863) address some of these questions and provide some pragmatic guidelines. These guidelines are influenced by the increasing evidence

Correspondence to: Dr A P Garnham, Sports Injury Prevention Research Unit, School of Health Sciences, Deakin University, 221 Burwood Highway, Burwood, 3125 Australia; agamm@deakin.edu.au of the potential harm produced by NSAID, as discussed by Stuart Warden ${ }^{4}$ in BJSM last month (and picked up by the New York Times!). Complications of specific concern to sport include dependence, prolonged on-field bleeding and electrolyte and renal disturbance in endurance events. Injected NSAID have been reported to cause Nicolau syndrome-a rare but severe localised adverse drug reaction, which manifests as acute pain and tissue necrosis immediately following an injection, with potentially devastating sequelae. ${ }^{5}$

\section{INFLAMMATION PARADOX: NOT SUCH A BAD THING?}

Sports physicians must re-examine the view that inflammation is inherently a bad thing. Certainly some aspects of it appear deleterious to recovery, but it is the pathway to tissue repair. It is overly simplistic to think that if a drug is "anti" something it must be good. We may yet see a move to pro-inflammatory agents as part of injury management and tissue regeneration after intense effort. It is already known that the widely used antioxidants, vitamins $\mathrm{C}$ and $\mathrm{E}$, may prevent the beneficial effects of exercise in insulin resistance and type 2 diabetes mellitus. ${ }^{6}$ Education is a very important tool in developing rational prescribing for physician and patient alike. Athletes are well aware that NSAID may alleviate symptoms and that they are readily available. Experience from the UK Drug Information Database ${ }^{7}$ (see page 811) and surveys undertaken at many major sporting events reveal both the extent of use and the need for knowledge. NSAID repeatedly appear at the top of the popularity charts. There are many opportunities for official agencies to send clear advice to their target population. Some drugs are abused in sporting competition because of rumours that they will be effective. Inhaled methamphetamine has no measurable effect in cycling. Dufka et $a l^{8}$ (see page 832) hopefully puts to rest the belief that one commonly available nasal remedy may be an effective stimulant, albeit of questionable legality.

\section{WOULD YOU TAKE A DRUG TO WIN A GOLD MEDAL AND THEN DIE?}

Everyone is prone to temptation, especially when one is competitive and the stakes are high. This has been well illustrated by the Goldman Dilemma, ${ }^{9}$ (see page 871) whereby repeated surveys have shown that approximately half of a sample of worldclass athletes would choose to take an undetectable illegal performance-enhancing drug guaranteeing an Olympic gold medal, in the knowledge that it would kill them within 5 years. James Connor sought to test this bargain further in the general population and establish a control group to analyse better why athletes may be more susceptible to temptation. Unfortunately, using similar methodology to that in athlete surveys, almost no one was willing to accept the bargain. ${ }^{\text {Therefore, the }}$ effective analysis of a control group became useless. Commonplace medications can sometimes lead to unexpected and unwanted outcomes. Whereas no athlete should die in the course of treatment of a muscle strain, in educating and treating athletes we must be mindful of the diverse and sometimes extreme influences that shape their needs and desires.

PS: Urgent! Please check the BJSM Blog (http://blogs.bmj.com/bjsm) for the announcement about the 2011 IOC World Conference on Prevention of Injury \& Illness in Sport (Monaco). It sounds like a long way off but proposals for keynote lectures, symposia and workshops must be in by 1 November 2009_act now!

Competing interests: $A G$ is the President of The Australasian College of Sports Physicions.

Accepted 3 September 2009

Br J Sports Med 2009;43:805-806.

doi:10.1136/bjsm.2008.067058

\section{REFERENCES}

1. Orchard JW, Best TM, Mueller-Wohlfahrt HW, et al. The early management of muscle strains in the elite athlete: best practice in a world with a limited evidence basis. Br J Sports Med 2008;42:158-9.

2. Balius R, Maestro A, Pedret C, et al. Central aponeurosis tears of the rectus femoris: practical sonographic prognosis. Br J Sports Med 2009;43:818-24.

3. Paoloni JA, Milne C, Orchard J, et al. Non-steroidal anti-inflammatory drugs in sports medicine: guidelines for practical but sensible use. Br J Sports Med 2009; 43:863-5.

4. Warden SJ. Prophylactic misuse and recommended use of non-steroidal anti-inflammatory drugs by athletes. Br J Sports Med 2009;43:548-9. 
5. Hamilton B, Fowler P, Galloway H, Popovic N. Nicolau syndrome in an athlete following intra-muscular diclofenac injection. Acta Orthop Belg 2008;74:860-4.

6. Ristow M, Zarse K, Oberbach A, et al. Antioxidants prevent health-promoting effects of physical exercise in humans. Proc Natl Acad Sci U S A 2009;106:8665-70.
7. Petróczi A, Naughton DP. Popular drugs in sport: descriptive analysis of the enquiries made via the Drug Information Database (DID). Br J Sports Med 2008:43:811-17.

8. Dufka F, Galloway G, Baggott M, et al. The effects of inhaled L-methamphetamine on athletic performance while riding a stationary bike: a randomised placebo-controlled trial. $\mathrm{Br} J$ Sports Med 2008:43:832-5

9. Connor JM, Mazanov J. Would you dope? A general population test of the Goldman dilemma. Br J Sports Med 2009; 43:871-2. 